\title{
African Lions and Zoonotic Diseases: Implications for Commercial Lion Farms in South Africa
}

\author{
Jennah Green ${ }^{1}$, Catherine Jakins ${ }^{2}$, Eyob Asfaw ${ }^{1}$, Nicholas Bruschi ${ }^{1}$, Abbie Parker ${ }^{1}$, \\ Louise de Waal ${ }^{2}$ and Neil D'Cruze ${ }^{1, *}$ \\ 1 World Animal Protection 222 Gray's Inn Rd., London WC1X 8HB, UK; \\ JennahGreen@worldanimalprotection.org (J.G.); EyobAsfaw@worldanimalprotection.org (E.A.); \\ NicholasBruschi@worldanimalprotection.org (N.B.); AbbieParker@worldanimalprotection.org (A.P.) \\ 2 Blood Lion NPC, P.O. Box 1548, Kloof 3640, South Africa; cathjakins@gmail.com (C.J.); \\ louise@greengirlsinafrica.com (L.d.W.) \\ * Correspondence: NeilDCruze@worldanimalprotection.org
}

Received: 21 August 2020; Accepted: 17 September 2020; Published: 18 September 2020

Simple Summary: In South Africa, thousands of African lions are bred on farms for commercial purposes, such as tourism, trophy hunting, and traditional medicine. Lions on farms often have direct contact with people, such as farm workers and tourists. Such close contact between wild animals and humans creates opportunities for the spread of zoonotic diseases (diseases that can be passed between animals and people). To help understand the health risks associated with lion farms, our study compiled a list of pathogens (bacteria, viruses, parasites, and fungi) known to affect African lions. We reviewed 148 scientific papers and identified a total of 63 pathogens recorded in both wild and captive lions, most of which were parasites $(35,56 \%)$, followed by viruses $(17,27 \%)$ and bacteria $(11,17 \%)$. This included pathogens that can be passed from lions to other animals and to humans. We also found a total of 83 diseases and clinical symptoms associated with these pathogens. Given that pathogens and their associated infectious diseases can cause harm to both animals and public health, we recommend that the lion farming industry in South Africa takes action to prevent and manage potential disease outbreaks.

Abstract: African lions (Panthera leo) are bred in captivity on commercial farms across South Africa and often have close contact with farm staff, tourists, and other industry workers. As transmission of zoonotic diseases occurs through close proximity between wildlife and humans, these commercial captive breeding operations pose a potential risk to thousands of captive lions and to public health. An understanding of pathogens known to affect lions is needed to effectively assess the risk of disease emergence and transmission within the industry. Here, we conduct a systematic search of the academic literature, identifying 148 peer-reviewed studies, to summarize the range of pathogens and parasites known to affect African lions. A total of 63 pathogenic organisms were recorded, belonging to 35 genera across 30 taxonomic families. Over half were parasites $(35,56 \%)$, followed by viruses $(17,27 \%)$ and bacteria $(11,17 \%)$. A number of novel pathogens representing unidentified and undescribed species were also reported. Among the pathogenic inventory are species that can be transmitted from lions to other species, including humans. In addition, 83 clinical symptoms and diseases associated with these pathogens were identified. Given the risks posed by infectious diseases, this research highlights the potential public health risks associated with the captive breeding industry. We recommend that relevant authorities take imminent action to help prevent and manage the risks posed by zoonotic pathogens on lion farms.

Keywords: zoonotic disease; Panthera leo; human health; biosecurity; wildlife farming; wildlife trade; disease transmission 


\section{Introduction}

Zoonotic diseases are infectious diseases caused by pathogenic agents (including bacteria, parasites, fungi, viruses, and prions) that can be transmitted between vertebrate mammals and humans [1]. Outbreaks of zoonotic diseases can have widespread consequences for public health and are thought to cause two billion cases of human illness and over two million human deaths every year [2]. Disease outbreaks from wild animal sources periodically result in hundreds of billions of dollars of economic damage [3]. The most recent global health pandemic, coronavirus COVID-19, which was also thought to originate in a wild animal host [4], is likely to cost the global economy between 5-9 trillion USD [5].

The increasing rate of emerging infectious diseases is thought to be a result of human-induced changes in land use, extraction of natural resources, animal production systems, and the global wildlife trade [6,7]. Wildlife harbor a large and often unknown reservoir of infectious diseases [8] and zoonotic disease transmission to people occurs when wild animals are in close proximity with human activity [6]. Most recent global health pandemics [9], including COVID-19, are thought to have originated in wild animal hosts [4]. A range of solutions could be put in place to prevent future zoonotic epidemics (see Petrovan et al. [10]). However, it has been suggested that efforts to decrease contact between wild animals and humans could prove to be the most practical and cost-effective approach in reducing the global public health threat posed by zoonotic emerging infectious diseases [11].

Commercial use of wildlife, whether legal or illegal, puts humans in direct contact with a range of wild species [12]. Wildlife farms (herein referred to as facilities that breed non-domesticated species for commercial purposes) in particular can create opportunity for pathogen transmission between wild animals and their human caretakers because of regular or prolonged contact for husbandry purposes [13]. Furthermore, conditions often associated with wildlife farms, such as high concentrations of wild animals in the same enclosures, poor hygiene, and stress associated with captive conditions, can reduce resistance to pathogens and increase the risk for transmission of disease [14,15].

A diverse range of wild animal species are farmed around the world for a range of commercial purposes, for example as exotic pets (e.g., snake farms in West Africa [16]), traditional medicine (e.g., bear bile farms in China and South-East Asia [17]), leather (e.g., alligators farms in the USA [18]), or fur (e.g., mink and fox farms in Europe [19]). Cases of infectious disease emergence from pathogen transmission among farmed wildlife have been documented from across the taxonomic spectrum. For example, transmission of zoonotic tape worm Armillifer armillatus from snakes to a farm owner was reported in The Gambia [20], and rapid transmission of coronavirus COVID-19 occurred recently between mink and farm workers at a mink farm in the Netherlands [21].

African lions (Panthera leo) are bred and kept on commercial farms across South Africa. These lions are bred for a range of purposes that can involve direct contact with people, including interactive tourism experiences (e.g., paying international volunteers working with predators and day tourists involved in cub petting and walking activities), recreational hunting for 'trophies', and bone exports to Asia for use in traditional medicine products [22,23]. For example, lion bone and trophy exports require a number of 'middle-men' who are required to have direct contact with lions and/or handle their derivatives during transport, slaughter, and/or preparation. This relatively high level of direct contact between lions and people (or consumption of their parts and derivatives) provides ample opportunity for zoonotic exchange.

A review of diseases present among lions in the Kruger Park during the 1970s provides an important insight into the variety of infectious diseases that can affect populations in the wild (e.g., trichinosis, filariasis, sarcoptic mange, pentastomiasis, echinococcosis, taeniasis, hepatozoonosis, anthrax, and babesiosis), including some that are considered to be either directly or indirectly transmissible to humans [24]. Likewise, scientific studies have reported the transmission of zoonotic infectious diseases between humans and captive lions. For example, in 2015, a zoo-housed lion cub presented with 'dermatophytosis', a disease caused by infection with pathogenic fungi Epidermophyton, 
Microsporum, or Trichophyton, was also contracted by a zookeeper caring for the lion as a result of continuous contact with the animal [25].

The number of lions bred on farms in South Africa has grown exponentially in the last two decades to a current captive population of up to 8500 individuals housed across more than 300 facilities [22]. The vast scale of these intensive breeding facilities further increases the number of people in close contact with lions and the opportunities for zoonotic disease transmission. Yet, to the authors' knowledge, despite its value for informing efforts to prevent, monitor, and manage any associated zoonotic disease outbreaks, no attempt has yet been made to compile a list of pathogenic organisms associated with African lions from recent scientific studies. Consequently, this review of the academic literature published in the last ten years provides an initial baseline of pathogenic organisms and discusses the potential animal and public health risks associated with the captive predator industry.

\section{Materials and Methods}

We conducted a systematic review of the scientific literature using the academic journal database Web of Science (Philadelphia, PA, USA). A total of 13 search terms relating to pathogenic health were searched on the database (Disease, Pathogen, Virus, Viral, Bacteria, Bacterial, Parasite, Parasitic, Fungus, Fungal, Zoonosis, Zoonotic, and Health). Each search term was employed with the Boolean operator 'AND', with the additional term Panthera leo. Searches were conducted for the time period 2009-2019, which returned a total of 252 results, comprising 152 individual academic papers. Of the 152 papers returned from the literature search, one could not be sourced due to institutional access and three were excluded because they were not published in English. The remaining 148 papers are included in the analysis.

Each paper was examined by one of six reviewers, who recorded any mention of 'bacteria', 'fungi', 'parasite', 'protozoa', or 'virus' in each article. All disorders, diseases, or conditions were recorded in relation to African and Asiatic lions, with a list of specific named pathogenic organisms compiled. The environment in which the lions were studied was recorded (wild or captive) with specific details on the type of captivity lions were housed in (commercial enterprises, zoos, private ownership, or mixed purposes). In addition, the papers were reviewed for information about disease transmission. The reviewers recorded where it was specified that pathogenic organisms were transmissible between African lions and other animal species, as well as between African lions and humans.

\section{Results}

A total of 63 different pathogenic organisms, known to affect lions, were reported (Table 1). Over half of the reported pathogenic organisms were parasites $(35,56 \%)$, including ticks (order Ixodida) $(4,6 \%)$, followed by viruses $(17,27 \%)$, and bacteria $(11,17 \%)$, with no pathogenic fungi reported. These 63 pathogenic organisms belong to 35 different genera across 30 different taxonomic families. Three novel pathogenic organisms representing unidentified and undescribed species were also reported.

The review also identified a total of 83 clinical symptoms and diseases associated with these pathogenic organisms (Table 2), highlighting the range of detrimental health risks that these pose to their feline hosts. With regards to information on the transmission of infectious disease, 38 (26\%) of the scientific papers referred to transmission between lions and other species and three ( $2 \%)$ specifically referred to transmission between lions and humans. 
Table 1. Pathogenic organisms (categorized into bacteria, parasites, and viruses) specified in the 148 papers in the dataset.

\begin{tabular}{|c|c|c|c|}
\hline Pathogen Type & Family & Genus/Species & Source \\
\hline \multirow[t]{10}{*}{ Bacteria } & Actinomycetaceae & Actinomyces & [26] \\
\hline & Anaplasmataceae & Ehrlichia canis & [27] \\
\hline & Bartonellaceae & $\begin{array}{c}\text { Bartonella koehlerae subsp. boulouisii; } \\
\text { Bartonella henselae }\end{array}$ & [28] \\
\hline & Clostridiaceae & Clostridia & [26] \\
\hline & Enterobacteriaceae & Escherichia coli & {$[26]$} \\
\hline & Mycobacteriaceae & Mycobacterium bovis & [29-38] \\
\hline & Mycoplasmataceae & Mycoplasma haemominutum & {$[39,40]$} \\
\hline & & Mycoplasma Hemoplasma spp. & [41] \\
\hline & Rickettsiaceae & Anaplasma phagocytophilum & [27] \\
\hline & Streptococcaceae & Alpha-hemolytic streptococcus & [26] \\
\hline \multirow[t]{17}{*}{ Viruses } & Paramyxoviridae & Morbillivirus spp. & {$[42,43]$} \\
\hline & & Canine distemper virus & {$[32,37,42,44-59]$} \\
\hline & Caliciviridae & Feline calcivirus & {$[44,47,51,56,60-62]$} \\
\hline & & Sapovirus Norovirus & [56] \\
\hline & Herpesviridae & Feline herpes virus & {$[44,47,51,60,62]$} \\
\hline & Retroviridae & Feline immunodeficiency virus & {$[32,38,47,51,52,57,60,62-71]$} \\
\hline & & Feline lentivirus & [72] \\
\hline & & Feline leukemia virus & {$[65,73,74]$} \\
\hline & & Feline panleukopenia virus & {$[44,51,61]$} \\
\hline & & Gammaretrovirus & [74] \\
\hline & Parvoviridae & feline panleukopenia virus & [51] \\
\hline & & Parvovirus & [75] \\
\hline & Coronaviridae & Feline coronavirus & {$[47,62]$} \\
\hline & Picobirnaviridae & Picobirnavirus & [76] \\
\hline & Reoviridae & Mammalian orthoreovirus & [77] \\
\hline & Papillomaviridae & Papillomavirus & [78] \\
\hline & Smacoviridae & Smacovirus & [79] \\
\hline \multirow[t]{32}{*}{ Parasites } & Babesiidae & Babesia canis & {$[80,81]$} \\
\hline & & Babesia felis & {$[80,82]$} \\
\hline & & Babesia lengau & [80] \\
\hline & & Babesia leo & {$[27,80,82]$} \\
\hline & & Babesia. spp. & {$[32,51,82]$} \\
\hline & & Babesia vogeli & {$[27,80]$} \\
\hline & & Novel babesia (similar to lengau) & [80] \\
\hline & & Rhipicephalus simus; & \\
\hline & Ixodidae & Rhipicephalus sulcatus; & [51] \\
\hline & & Rhipicephalus appendiculatus & \\
\hline & & Rhipicentor nuttalli & [51] \\
\hline & Angiostrongylidae & Aelurostrongylus abstrusus & {$[83]$} \\
\hline & & Aelurostrongylus spp. & {$[83,84]$} \\
\hline & Sarcocystidae & Cystoisospora spp. & {$[85]$} \\
\hline & & Cystoisospora felis like oocysts; & [86] \\
\hline & & Cystoisospora rivolta like oocysts & {$[86]$} \\
\hline & & Sarcocystis spp. & [84] \\
\hline & & Toxoplasma gondii & {$[87,88]$} \\
\hline & Theileriidae & Cytauxzoon manul & [27] \\
\hline & & $\begin{array}{l}\text { Theileria parva; } \\
\text { Theileria sinensis }\end{array}$ & [27] \\
\hline & Diphyllobothriidae & Spirometra pretoriensis & [89] \\
\hline & & Spirometra ranarum & {$[89,90]$} \\
\hline & & Spirometra theileri & [89-91] \\
\hline & & Spirometra spp. & {$[84,85,92]$} \\
\hline & & Trypanosome b. rhodesiense; & \\
\hline & Trypanosomatidae & Trypanosome congolense; & [93] \\
\hline & & $\begin{array}{l}\text { Trypanosome brucei s.l. } \\
\text { Taeniid cestodes }\end{array}$ & \\
\hline & Taeniidae & $\begin{array}{l}\text { Taeniid cestodes } \\
\text { Taeniid spp. }\end{array}$ & $\begin{array}{l}{[84]} \\
{[85]}\end{array}$ \\
\hline & Toxocaridae & Toxascaris leonine & {$[94,95]$} \\
\hline & & Toxocara cati & {$[84]$} \\
\hline & Trichinellidae & Trichinella spp. & [96] \\
\hline & Hepatozoidae & $\begin{array}{l}\text { Hepatozoon canis; } \\
\text { Hepatozoon felis }\end{array}$ & {$[27,82]$} \\
\hline
\end{tabular}


Table 2. Associated diseases and clinical symptoms recorded in the 148 papers in the dataset.

\begin{tabular}{c} 
Terms from Source Papers \\
\hline Category \\
Babesiosis [54]; bovine tuberculosis [29,30,32-34,37,47,52,62,64,71,97-99]; \\
echinococcosis [52]; bilateral pulmonary disease [100]; encephalitis [42,43]; neurologic \\
disease [43,50]; gingivitis [69]; gallbladder adenocarcinomas [26]; kidney disease [26]; \\
biliary cystadenomas [26]; bacterial septicemia [26]; interstitial pneumonia [26,43]; \\
necrotizing and neutrophilic hepatitis [26]; rabies [53]; pneumonia [94] \\
Acute neurologic involvement [50]; anemia [32]; anisokaryosis [78]; anorexia [41,42,50]; \\
ataxia [43,100]; bilateral submandibular swelling [100], cachexia [69]; congested lungs \\
[26]; corneal opacity [100]; dehydration [26,32,69]; dehydration and hypertension due \\
to kidney disease [101]; depletion of lymphoid organs [50]; depressed serum albumin \\
[32]; profound depression or stupor [43]; dermal and/or mucocutaneous perioral \\
masses [78]; diarrhea [94,95]; disorientation [43]; dyspnea [100]; elbow hygroma [33]; \\
emaciation [33,35,100]; enlarged abdominal area [26]; facial and forelimb myoclonus \\
(recurrent twitching) [43]; feline sarcoids [78]; fibropapilloma [78]; grand mal seizure \\
[43]; hematologic derangements [64]; hyperglobulinemia [69]; immune depletion [70]; \\
convulsions [102]; head tilt [102]; opisthotonos [102]; incoordination [102]; blindness \\
[102]; hypoalbunemia [32]; monoytosis [32]; intraductular cholestasis [26]; ivermectin \\
induced blindness [103]; lethargy [41]; leukopenia [75]; loss of coat condition [69]; \\
lymphadenopathy [33,69]; lymphocytic depletion in lymph nodes and spleen [69]; \\
lymphopenia [42]; hyperglobulinemia [32]; macroscopic abnormalities in the liver [26]; \\
malnutrition [95]; mandibular swelling [33]; mange [33]; marked alopecia [100]; nasal \\
discharge [42]; neutrophilic splenitis [26]; nodular polycystic lesion [26]; obstruction of \\
the intestine [94]; papillomas [69]; peribiliary cysts [26]; polycystic liver [26]; \\
pulmonary and bone lesions [35]; pyrexia [42]; severe seizures [104]; shoulder abscess \\
[33]; tachypnoea [100]; vomiting [94,95] \\
Clinical symptoms
\end{tabular}

Of the 109 papers that focused on African lions, 45 (41\%) were based on data from captive lions, $61(56 \%)$ from wild lions, and three (3\%) from a mixture of both. Of the studies focusing on captive lions, only one collected data from a commercial breeding facility in South Africa. The study used samples from three deceased lions to analyze their evolutionary history and was unrelated to pathogens or disease. One further study focused on commercial facilities in South Africa but did not collect first-hand data and instead used literature sources to review the suitability of captive bred lions for reintroduction into the wild. The remainder of the captive data came from lions housed in zoos, wildlife sanctuaries, and reserves $(34,76 \%)$, in private ownership $(5,11 \%)$, or a combination of both $(4,9 \%)$.

\section{Discussion}

A systematic review of scientific literature confirmed that a range of 63 different pathogenic organisms are known to exist in both captive and wild free ranging lions (Tables 1 and 2). A number of novel pathogenic organisms, in some cases representing unidentified and undescribed species, were reported, including novel Babesia species and Cystoisospora-resembling oocysts.

There is a paucity of knowledge on disease susceptibility, transmission, epidemiology, and pathology in lions [100]. While the list of known pathogenic organisms will undoubtedly grow, this review provides an important baseline inventory. Given the conditions in which the lion farming industry currently operates, the considerable scale of trade in lions, and their susceptibility to such a wide range of multi-host pathogenic organisms, it is likely that farmed lions could play a central role in the emergence, amplification, and transmission of disease to both people and wild animal populations.

\subsection{Significance for Lion Health}

Some of the pathogenic organisms reported in this review are of significant health concern for captive and wild lions. For example, Babesia parasites, Mycobacterium bovis (a bacteria known for 
causing tuberculosis), canine distemper virus (CDV), canine parvovirus (CP), and feline panleukopenia virus (FPLV) (Table 1) are all highly contagious and cause significant morbidity and mortality in susceptible carnivore species. Infection with these pathogens is associated with a range of clinical symptoms, including but not limited to: emaciation, alopecia, diarrhea, seizures, recurrent twitching, and depression (Table 2) from which infected lions can suffer.

Some of these pathogenic organisms are particularly difficult to manage because infection of susceptible animals does not require direct physical contact. Infected lions shed pathogenic organisms in feces and other bodily secretions, e.g., aerosolized respiratory secretions [105,106] facilitating environmental contamination and rapid spread of disease. Furthermore, some of these organisms have longer incubation periods and can therefore lie undetected in the animals' systems until they reach hazardous levels. For example, tuberculosis onset is slow, in many cases with the majority of infected lions initially appearing healthy $[100,107]$. In a captive setting, this renders detection and prevention of spread of infections between individuals housed together very difficult.

In addition, some of these pathogenic organisms are likely to present a management challenge on commercial lion farms, as the onset of disease in lions often occurs suddenly after high stress situations, for example after repeated periods of pregnancy and lactation [100]. It has been suggested that intensive farming conditions and poor hygiene may be increasing the incidence of FPLV in captive carnivores, such as lions [108]. Disease transmission is promoted in immunocompromising conditions, and direct human-wildlife contact mixed with limited health and safety standards are all criteria for an emerging zoonosis hotspot [12].

Another challenge for captive facilities is that seemingly innocuous pathogens can cause harm when lions are 'co-infected' with multiple pathogens. For example, severe mortalities have occurred when individual lions were infected with both babesiosis and CDV, resulting in severe diseases like pneumonia and encephalitis, despite appearing healthy when infected with babesiosis alone [81]. This heightens the challenge of identifying infected individuals to manage diseases before transmission can occur.

\subsection{Significance for Human Health}

In addition to the potential significance for lion health, many of the pathogenic organisms reported in the reviewed scientific literature raise concerns for human health. For example, pathogenic strains of the Enterobacteriaceae Escherichia coli [26], the parasitic Sarcocystidae Toxoplasma gondii [14,87], and potentially, the parasitic Toxocaridae Toxascaris leonine [109] have a possible fecal-oral transmission route from lions to humans. For others, such as the Rickettsiaceae Anaplasma phagocytophilum [27], transmission via the bite of an infected arthropod tick is also possible.

Some pathogens possess the capacity to infect human tissue using keratin and therefore only require physical contact with the lion's fur; for example, Microsporum gypseum, the cause of dermatomycosis [110]. The adoption of prophylactic measures for sanitary maintenance for these animals and the professionals who maintain contact with them is paramount to reduce possible transmission of infection but is difficult to manage because of the asymptomatic nature of the pathogens in healthy lions [110]. Visitors to lion farms in South Africa have reported that basic hygiene protocols, for example hand sanitizing and stepping points to disinfect shoes between enclosures, are often absent for those intending to interact with the animals [111].

Lions have also been reported as hosts for diseases listed by the World Health Organization (WHO) as 'neglected tropical diseases (NTDs)' [112]. For example, human African trypanosomiasis caused by trypanosomes are multi-host parasites capable of infecting a wide range of wildlife species, including lions [93], that constitute a reservoir of infection for both people and domestic animals. Echinococcosis, a parasitic disease caused by tapeworms that reside in the intestines of carnivores, including lions [52], can cause serious morbidity and death in people. The prevalence of Echinococcosis is increasing in some African countries due to frequent contact between game animals (reservoir hosts), domestic animal 
hosts (such as dogs), and humans who are susceptible to transmission [113]. Neglecting these parasites can have severe socioeconomic consequences [113].

Captive carnivores can be predisposed to infections of Toxoplasma, a protozoan parasite with significant zoonotic potential [113]. Lions in particular have been identified as a susceptible host species [113]. Lions infected with Toxoplasma can transmit the parasites to people via blood and feces, causing severe pulmonary, cardiac, and brain inflammatory reactions (among others), sometimes with fatal outcomes [113]. Some Toxoplasma species have also been reported to cause abortion and fetal death; underestimating the impact of these parasites on humans could lead to a future epidemic where reduction in life expectancy, and increased child and maternal death, are rife [113].

Lions are also vulnerable to bovine tuberculosis (bTB), a disease caused by infection with the bacterial pathogen M. bovis [32,47]. Tuberculosis transmission at the wildlife-livestock-human interface is a growing concern worldwide, particularly in sub-Saharan Africa where infection is spreading [114]. Lions initially contracted bTB from infected buffalo carcasses [32], and although no direct spill-over from wildlife to humans (or vice-versa) has yet been documented [114], it is a growing concern, particularly in countries such as South Africa where there are a relatively high number of people living with HIV $[115,116]$ and because HIV is the strongest known risk factor for TB [32]. Transmission of other pathogenic strains of tuberculosis from wild captive animals to humans has already been documented [117].

Epidemics caused by cats are possible (e.g., canine distemper in big cats) but are considered to be relatively rare [118]. While no evidence of lion-to-human transmission of feline coronavirus exists, isolation of pathogens with pandemic potential from any mammalian host is significant as it may provide conditions suitable for the virus to adapt to other mammalian hosts, enabling efficient mammal-to-human, and possibly also human-to-human, transmission, paving the way for a potentially devastating pandemic [119].

For example, it has recently been confirmed that big cats, including lions, can be infected with Sars-CoV-2 [120]. Some experts have publicly stated their belief that it is unlikely Sars-CoV-2 will naturally spread in a wild big cat population [118]. However, given the fact that the lions and tigers that tested positive for Sars-CoV-2 in the Bronx Zoo were likely to be infected by a zoo employee [121,122], there are on-going concerns that this virus could be passed from humans to big cats and vice versa in scenarios that involve captive individuals [118].

\subsection{Significance for Lion Farming}

The maintenance of wild species in captivity provides an opportunity for unnatural human-wildlife proximity, facilitating interspecies sharing of pathogenic organisms [123]. Lions are kept in captivity in zoos in many cases as part of conservation breeding programs [124], but also, and in far greater numbers, on commercial wildlife farms [125]. While published data detailing the scale of wildlife farming and lion farming in particular in South Africa are scant, the South African Minister of Environment, Forestry and Fisheries stated in July 2019 in response to a Parliamentary question that the captive lion population in South Africa amounted to 7979 lions housed across 366 facilities.

Scientific papers that focus on the welfare conditions on commercial lion farms prevalent across South Africa are currently lacking. However, the living conditions and environments provided are frequently reported as low welfare, involving large numbers of lions, often in poor physical condition and in over-crowded spaces [126,127] (Figure 1). High concentrations of wild animals in the same enclosures can increase the risk for transmission of disease to and from wild animals due to reduced resistance to pathogens from factors associated with captivity, such as poor hygiene, poor diet, or stress $[14,128]$. Furthermore, cub separation from their mothers and the provision of alternative milk formulas (a practice reported at some lion farms [111]] can lead to nutritional deficiencies [129], which weakens immune systems and leaves animals more susceptible to pathogens [130]. 


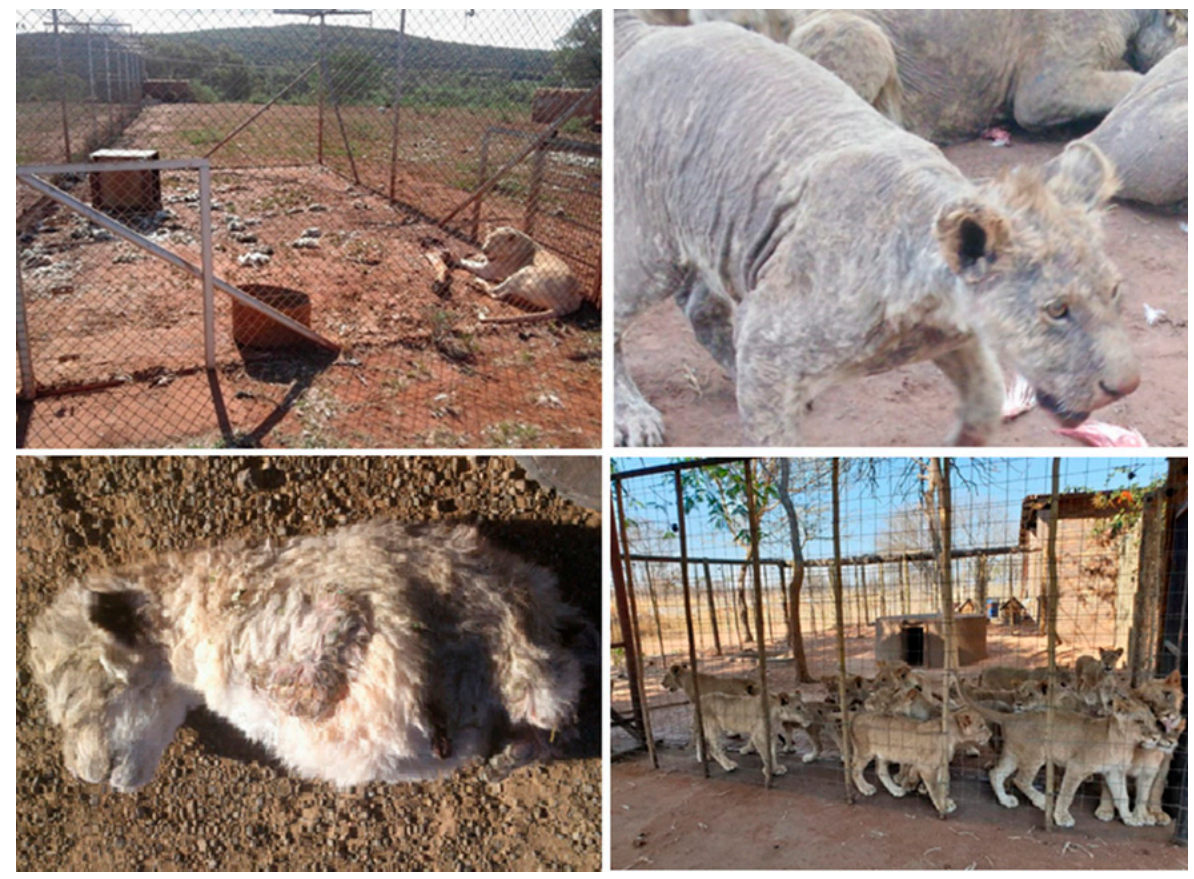

Figure 1. Environments provided for lions at commercial captive breeding facilities in South Africa are frequently reported as low welfare, involving large numbers of lions, often in poor physical condition and in over-crowded spaces. (Top left) Lioness housed in an enclosure with fecal matter and decaying carcasses. (Top right) Lions with little to no fur left as a result of severe and untreated mange. (Bottom left) Lion cub born with severe deformities, likely due to inbreeding. (Bottom right) Lions housed in overcrowded conditions. Images copyright Blood Lions.

A key part of this industry is "ecotourism", where people are provided with the opportunity to come into close and unnatural proximity with lions via cub "petting" and "walking with" interactions or international volunteers paying to hand-rear lion cubs. The process of preparation of carcasses for human consumption also presents a considerable risk for transmission of disease to and from wild animals [131], a risk that is amplified in situations where slaughter and preparation take place at unregulated slaughterhouses, unbound by official hygiene standards [132]. Furthermore, the regulatory body that governs the international export of lion bones (The Convention of International Trade of Endangered Species, 'CITES') dictates quotas based on conservation science [133] and is not specifically aimed at preventing zoonotic disease introduction, despite the major role wildlife trade has as a transmission pathway for pathogenic organisms [12].

It is also important to note that any pathogenic organisms present in the captive lion population may pose a threat to the conservation of wild populations, particularly in scenarios where lion farms are located close to a wild lion habitat and where lion farm staff and visitors are actively engaged in other activities (e.g., conservation-focused field research, hunting, and photo tourism) that bring them into close proximity to free-ranging lions. For example, wild racoon dogs (Nyctereutes procyonoides) are thought to have transmitted CDV to a group of zoo-housed tigers in Japan [42] and records of transmission of intestinal nematodes between captive felids and local feral cats have been reported in Brazil [134]. Multi-host pathogenic organisms may pose a particular threat in scenarios where lion farm activity overlaps with areas inhabited by other free-ranging carnivore species (both wild and domesticated).

\subsection{Mitigating Animal and Public Health Risks}

Remedial measures, such as improved animal welfare standards, veterinary interventions, and biosecurity protocols can partially mitigate the risk of zoonosis at captive lion breeding facilities [135]. However, due to the potential of asymptomatic pathogens affecting lions [110], 
biosecurity would require sophisticated disease surveillance, which could prove challenging [136,137]. Even with comprehensive surveillance, identification of emerging pathogens is still a challenge that poses significant animal and public health risks [12]. There is currently no publicly available information detailing the biosecurity protocols and regulatory standards within the lion breeding industry and, from our initial review of the literature, an apparent lack of national norms and standards for the health of the lions housed on commercial farms.

Alternatively, a phased reduction in the scale of, or end to, the commercial captive breeding of lions for non-conservation purposes in South Africa could help to remove the animal and public health risks associated with this industry. However, efforts focused on improving animal husbandry, reducing consumer demand for lions (and their derivatives), increased enforcement effort, and the provision of economic incentives for farm staff would need to be considered to prevent any unintended consequences on lion welfare, conservation, and local livelihoods.

\subsection{Limitations}

We acknowledge that restricting our search to a ten-year time period and to one academic database will limit the number of relevant articles in our review. In addition, we recognize that additional onsite research is required to determine the incidence and prevalence of particular pathogenic organisms (in both captive and wild lion populations) and to help identify which infectious diseases are more likely to affect them under certain conditions. However, it was not our intention to provide a comprehensive overview of all pathogens affecting African lions or to provide specific statistics on their occurrence. Rather, the aim of our study was to create a baseline inventory of key pathogens and associated diseases and to describe the potential associated health concerns for both lions and people. Although our review may omit some relevant pathogens, we hope to demonstrate that, by only scratching the surface of this field, we identify a previously neglected area of consideration that will stimulate increased attention in future.

\section{Conclusions}

There are many socio-cultural, political, economic, and conservation factors that create a complex and nuanced debate around the commercial captive lion breeding industry in South Africa [133]. However, all economic, ethical, and environmental considerations aside, the data presented here indicate that the industry poses a potential risk to wild animal and public health. This initial literature review reveals a long and varied list of pathogenic organisms known to affect African lions, some of which can be transmitted to people. Given the range of pathogens identified, the growth of the industry over the last couple of decades, and the increasing number of people who have direct contact with live lions and/or their parts and derivatives, we recommend that a closer examination of the current policies and practices associated with commercial lion farming is required, particularly under a biosecurity lens. Furthermore, to properly safeguard lion and public health, it is paramount that the recommendations of any such examinations should be acted on with clear time-bound objectives relating to both implementation and enforcement.

Author Contributions: Conceptualization, N.D., J.G. and L.d.W.; methodology, N.D. and J.G.; formal analysis, J.G.; investigation, N.D., J.G., C.J., L.d.W., E.A., A.P. and N.B.; resources, N.D., J.G., C.J., L.d.W., E.A., A.P. and N.B.; data curation, J.G.; writing-original draft preparation, J.G. and N.D.; writing-review and editing, J.G., N.D., L.d.W., C.J.; visualization, J.G.; supervision, N.D. and L.d.W.; project administration, J.G. All authors have read and agreed to the published version of the manuscript.

Funding: This research received no external funding.

Acknowledgments: We would like to thank Gilbert Sape, Edith Kabesiime, Patrick Muinde, and Paul Giess for providing helpful comments and feedback on an earlier version of this manuscript.

Conflicts of Interest: The authors declare no conflict of interest. 


\section{References}

1. Can, Ö.E.; D'Cruze, N.; Macdonald, D.W. Dealing in deadly pathogens: Taking stock of the legal trade in live wildlife and potential risks to human health. Glob. Ecol. Conserv. 2019, 17, e00515. [CrossRef] [PubMed]

2. Grace, D.; Gilbert, J.; Randolph, T.; Kang'ethe, E. The multiple burdens of zoonotic disease and an ecohealth approach to their assessment. Trop. Anim. Health Prod. 2012, 44, 67-73. [CrossRef]

3. Fukushima, C.S.; Mammola, S.; Cardoso, P. Global wildlife trade permeates the Tree of Life. Biol. Conserv. 2020, 247, 108503. [CrossRef]

4. Zhang, T.; Wu, Q.; Zhang, Z. Probable pangolin origin of SARS-CoV-2 associated with the COVID-19 outbreak. Curr. Biol. 2020, 30, 1346-1351.e2. [CrossRef] [PubMed]

5. Chapman, B. Coronavirus could Deliver $\$ 8.8$ Trillion Hit to Global Economy without Government Intervention, Bank Says. Independent 2020. Available online: https://www.independent.co.uk/news/business/news/ coronavirus-global-economy-impact-gdp-covid-19-a9516806.html (accessed on 28 August 2020).

6. Karesh, W.B.; Dobson, A.; Lloyd-Smith, J.O.; Lubroth, J.; Dixon, M.A.; Bennett, M.; Aldrich, S.; Harrington, T.; Formenty, P.; Loh, E.H.; et al. Ecology of zoonoses: Natural and unnatural histories. Lancet 2012, 380, 1936-1945. [CrossRef]

7. Smith, K.M.; Zambrana-Torrelio, C.; White, A.; Asmussen, M.; Machalaba, C.; Kennedy, S.; Lopez, K.; Wolf, T.M.; Daszak, P.; Travis, D.A. Summarizing US wildlife trade with an eye toward assessing the risk of infectious disease introduction. EcoHealth 2017, 14, 29-39. [CrossRef]

8. Levinson, J.; Bogich, T.L.; Olival, K.J.; Epstein, J.H.; Johnson, C.K.; Karesh, W.; Daszak, P. Targeting Surveillance for Zoonotic Virus Discovery. Emerg. Infect. Dis. 2013, 19, 743-747. [CrossRef] [PubMed]

9. Morse, S.S.; Mazet, J.A.; Woolhouse, M.; Parrish, C.R.; Carroll, D.; Karesh, W.B.; Zambrana-Torrelio, C.; Lipkin, W.I.; Daszak, P. Prediction and prevention of the next pandemic zoonosis. Lancet 2012, 380, 1956-1965. [CrossRef]

10. Petrovan, V.; Murgia, M.V.; Wu, P.; Lowe, A.D.; Jia, W.; Rowland, R.R. Epitope mapping of African swine fever virus (ASFV) structural protein, p54. Virus Res. 2020, 279, 197871. [CrossRef]

11. Karesh, W.B.; Cook, R.A.; Bennett, E.L.; Newcomb, J. Wildlife trade and global disease emergence. Emerg. Infect. Dis. 2005, 11, 1000. [CrossRef]

12. Watsa, M.; Group, W.D.S.F. Rigorous wildlife disease surveillance. Science 2020, 369, 145-147. [CrossRef] [PubMed]

13. Kimman, T.; Hoek, M.; de Jong, M.C. Assessing and controlling health risks from animal husbandry. NJAS Wagening J. Life Sci. 2013, 66, 7-14. [CrossRef]

14. Mukarati, N.L.; Vassilev, G.D.; Tagwireyi, W.M.; Tavengwa, M. Occurrence, prevalence and intensity of internal parasite infections of African lions (Panthera leo) in enclosures at a recreation park in Zimbabwe. J. Zoo Wildl. Med. 2013, 44, 686-693. [CrossRef] [PubMed]

15. Whitehouse-Tedd, K.M.; Lefebvre, S.L.; Janssens, G.P. Dietary factors associated with faecal consistency and other indicators of gastrointestinal health in the captive cheetah (Acinonyx jubatus). PLoS ONE 2015, 10, e0120903. [CrossRef]

16. Auliya, M.; Hofmann, S.; Segniagbeto, G.H.; Assou, D.; Ronfot, D.; Astrin, J.J.; Forat, S.; Ketoh, G.K.K.; D'Cruze, N. The first genetic assessment of wild and farmed ball pythons (Reptilia, Serpentes, Pythonidae) in southern Togo. Nat. Conserv. 2020, 38, 37. [CrossRef]

17. Dutton, A.J.; Hepburn, C.; Macdonald, D.W. A stated preference investigation into the Chinese demand for farmed vs. wild bear bile. PLoS ONE 2011, 6, e21243. [CrossRef]

18. Moyle, B. Conservation that's more than skin-deep: Alligator farming. Biodivers. Conserv. 2013, 22, $1663-1677$. [CrossRef]

19. Wong, T.C.; Ng, R.; Cai, L.M. Sustainability in the Fur Industry. In Sustainability in Luxury Fashion Business; Springer: New York City, NY, USA, 2018; pp. 133-152.

20. Tappe, D.; Meyer, M.; Oesterlein, A.; Jaye, A.; Frosch, M.; Schoen, C.; Pantchev, N. Transmission of Armillifer armillatus ova at snake farm, The Gambia, West Africa. Emerg. Infect. Dis. 2011, 17, 251-254. [CrossRef]

21. Enserink, M. Coronavirus rips through Dutch mink farms, triggering culls. Science 2020, 368, 1169. [CrossRef]

22. Hutchinson, A.; Roberts, D.L. Differentiating captive and wild African lion (Panthera leo) populations in South Africa, using stable carbon and nitrogen isotope analysis. Biodivers. Conserv. 2020, 1-19. [CrossRef]

23. Outhwaite, W. The Legal and Illegal Trade in African Lions; TRAFFIC: Cambridge, UK, 2018. 
24. Young, E. Some important parasitic and other diseases of lion, Panthera leo, in the Kruger National Park. J. S. Afr. Vet. Assoc. 1975, 46, 181-183. [PubMed]

25. Kim, K.T.; Lee, S.H.; mi Kwak, D. Dermatophytosis on an African lion and transmission to human. 대한수의 학회 학술대회발표집 2015, 543.

26. Caliendo, V.; Bull, A.C.; Stidworthy, M.F. Congenital biliary tract malformation resembling biliary cystadenoma in a captive juvenile African lion (Panthera leo). J. Zoo Wildl. Med. 2012, 43, 922-926. [CrossRef] [PubMed]

27. Kelly, P.; Marabini, L.; Dutlow, K.; Zhang, J.; Loftis, A.; Wang, C. Molecular detection of tick-borne pathogens in captive wild felids, Zimbabwe. Parasites Vvectors 2014, 7, 514. [CrossRef] [PubMed]

28. Molia, S.; Kasten, R.W.; Stuckey, M.J.; Boulouis, H.-J.; Allen, J.; Borgo, G.M.; Koehler, J.E.; Chang, C.C.; Chomel, B.B. Isolation of Bartonella henselae, Bartonella koehlerae subsp. koehlerae, Bartonella koehlerae subsp. bothieri and a new subspecies of B. koehlerae from free-ranging lions (Panthera leo) from South Africa, cheetahs (Acinonyx jubatus) from Namibia and captive cheetahs from California. Epidemiol. Infect. 2016, 144, 3237-3243. [PubMed]

29. Brüns, A.C.; Tanner, M.; Williams, M.C.; Botha, L.; O’Brien, A.; Fosgate, G.T.; Van Helden, P.D.; Clarke, J.; Michel, A.L. Diagnosis and implications of Mycobacterium bovis infection in banded mongooses (Mungos mungo) in the Kruger National Park, South Africa. J. Wildl. Dis. 2017, 53, 19-29. [CrossRef]

30. Cross, P.C.; Heisey, D.M.; Bowers, J.A.; Hay, C.T.; Wolhuter, J.; Buss, P.; Hofmeyr, M.; Michel, A.L.; Bengis, R.G.; Bird, T.L.F. Disease, predation and demography: Assessing the impacts of bovine tuberculosis on African buffalo by monitoring at individual and population levels. J. Appl. Ecol. 2009, 46, 467-475. [CrossRef]

31. Kosmala, M.; Miller, P.; Ferreira, S.; Funston, P.; Keet, D.; Packer, C. Estimating wildlife disease dynamics in complex systems using an Approximate Bayesian Computation framework. Ecol. Appl. 2016, 26, 295-308. [CrossRef]

32. Maas, M.; Keet, D.F.; Rutten, V.P.; Heesterbeek, J.A.P.; Nielen, M. Assessing the impact of feline immunodeficiency virus and bovine tuberculosis co-infection in African lions. Proc. R. Soc. B Biol. Sci. 2012, 279, 4206-4214. [CrossRef]

33. Miller, M.; Buss, P.; Hofmeyr, J.; Olea-Popelka, F.; Parsons, S.; van Helden, P. Antemortem diagnosis of Mycobacterium bovis infection in free-ranging African lions (Panthera leo) and implications for transmission. J. Wildl. Dis. 2015, 51, 493-497. [CrossRef]

34. Miller, M.; Joubert, J.; Mathebula, N.; De Klerk-Lorist, L.-M.; Lyashchenko, K.P.; Bengis, R.; van Helden, P.; Hofmeyr, M.; Olea-Popelka, F.; Greenwald, R. Detection of antibodies to tuberculosis antigens in free-ranging lions (Panthera leo) infected with Mycobacterium bovis in Kruger National Park, South Africa. J. Zoo Wildl. Med. 2012, 43, 317-323. [CrossRef] [PubMed]

35. Miller, M.A.; Buss, P.; Sylvester, T.T.; Lyashchenko, K.P.; deKlerk-Lorist, L.-M.; Bengis, R.; Hofmeyr, M.; Hofmeyr, J.; Mathebula, N.; Hausler, G. Mycobacterium bovis in free-ranging lions (panthera leo)—Evaluation of serological and tuberculin skin tests for detection of infection and disease. J. Zoo Wildl. Med. 2019, 50, 7-15. [PubMed]

36. Newkirk, K.M.; Beard, L.K.; Sun, X.; Ramsay, E.C. Investigation of enrofloxacin-associated retinal toxicity in nondomestic felids. J. Zoo Wildl. Med. 2017, 48, 518-520. [CrossRef] [PubMed]

37. Olivier, T.T.; Viljoen, I.M.; Hofmeyr, J.; Hausler, G.A.; Goosen, W.J.; Tordiffe, A.S.W.; Buss, P.; Loxton, A.G.; Warren, R.M.; Miller, M.A. Development of a Gene Expression Assay for the Diagnosis of M ycobacterium bovis Infection in African Lions (P anthera leo). Transbound. Emerg. Dis. 2017, 64, 774-781. [CrossRef] [PubMed]

38. Sylvester, T.T.; Martin, L.E.R.; Buss, P.; Loxton, A.G.; Hausler, G.A.; Rossouw, L.; van Helden, P.; Parsons, S.D.C.; Olea-Popelka, F.; Miller, M.A. Prevalence and risk factors for Mycobacterium bovis infection in African lions (Panthera leo) in the Kruger National Park. J. Wildl. Dis. 2017, 53, 372-376. [CrossRef] [PubMed]

39. de Sousa, K.C.M.; Herrera, H.M.; Secato, C.T.; do Vale Oliveira, A.; Santos, F.M.; Rocha, F.L.; Barreto, W.T.G.; Macedo, G.C.; de Andrade Pinto, P.C.E.; Machado, R.Z. Occurrence and molecular characterization of hemoplasmas in domestic dogs and wild mammals in a Brazilian wetland. Acta Trop. 2017, 171, 172-181. [CrossRef] 
40. Ribeiro, C.M.; de Matos, A.C.; Richini-Pereira, V.B.; Lucheis, S.B.; Azzolini, F.; Sipp, J.P.; Lima, P.P.; Katagiri, S.; Vidotto, O. Occurrence and phylogenetic analysis of 'Candidatus Mycoplasma haemominutum'in wild felines from Paraná, Brazil. Semin. Ciências Agrárias 2017, 38, 2837-2844. [CrossRef]

41. Krengel, A.; Meli, M.L.; Cattori, V.; Wachter, B.; Willi, B.; Thalwitzer, S.; Melzheimer, J.; Hofer, H.; Lutz, H.; Hofmann-Lehmann, R. First evidence of hemoplasma infection in free-ranging Namibian cheetahs (Acinonyx jubatus). Vet. Microbiol. 2013, 162, 972-976. [CrossRef]

42. Nagao, Y.; Nishio, Y.; Shiomoda, H.; Tamaru, S.; Shimojima, M.; Goto, M.; Une, Y.; Sato, A.; Ikebe, Y.; Maeda, K. An outbreak of canine distemper virus in tigers (Panthera tigris): Possible transmission from wild animals to zoo animals. J. Vet. Med. Sci. 2011, 1112250745. [CrossRef]

43. Roelke-Parker, M.E.; Munson, L.; Packer, C.; Kock, R.; Cleaveland, S.; Carpenter, M.; O’Brien, S.J.; Pospischil, A.; Hofmann-Lehmann, R.; Lutz, H. A canine distemper virus epidemic in Serengeti lions (Panthera leo). Nature 1996, 379, 441-445. [CrossRef]

44. Alexander, K.A.; McNutt, J.W.; Briggs, M.B.; Standers, P.E.; Funston, P.; Hemson, G.; Keet, D.; Van Vuuren, M. Multi-host pathogens and carnivore management in southern Africa. Comp. Immunol. Microbiol. Infect. Dis. 2010, 33, 249-265. [CrossRef] [PubMed]

45. Broekhuis, F.; Cushman, S.A.; Elliot, N.B. Identification of human-carnivore conflict hotspots to prioritize mitigation efforts. Ecol. Evol. 2017, 7, 10630-10639. [CrossRef] [PubMed]

46. Caillaud, D.; Craft, M.E.; Meyers, L.A. Epidemiological effects of group size variation in social species. J. R. Soc. Interface 2013, 10, 20130206. [CrossRef] [PubMed]

47. Hunter, L.T.; White, P.; Henschel, P.; Frank, L.; Burton, C.; Loveridge, A.; Balme, G.; Breitenmoser, C.; Breitenmoser, U. Walking with lions: Why there is no role for captive-origin lions Panthera leo in species restoration. Oryx 2013, 47, 19-24. [CrossRef]

48. Jackson, C.R.; Masenga, E.H.; Mjingo, E.E.; Davies, A.B.; Fossøy, F.; Fyumagwa, R.D.; Røskaft, E.; May, R.F. No evidence of handling-induced mortality in Serengeti's African wild dog population. Ecol. Evol. 2019, 9, 1110-1118. [CrossRef]

49. Jhala, Y.V.; Banerjee, K.; Chakrabarti, S.; Basu, P.; Singh, K.; Dave, C.; Gogoi, K. Asiatic lion: Ecology, economics and politics of conservation. Front. Ecol. Evol. 2019, 7, 312. [CrossRef]

50. Konjević, D.; Sabočanec, R.; Grabarević, Ž.; Zurbriggen, A.; Bata, I.; Beck, A.; Kurilj, A.G.; Cvitković, D. Canine distemper in Siberian tiger cubs from Zagreb ZOO: Case report. Acta Vet. Brno 2011, 80, 47-50. [CrossRef]

51. McDermid, K.R.; Snyman, A.; Verreynne, F.J.; Carroll, J.P.; Penzhorn, B.L.; Yabsley, M.J. Surveillance for viral and parasitic pathogens in a vulnerable African Lion (Panthera Leo) population in the Northern Tuli Game Reserve, Botswana. J. Wildl. Dis. 2017, 53, 54-61. [CrossRef]

52. Miller, S.M.; Bissett, C.; Burger, A.; Courtenay, B.; Dickerson, T.; Druce, D.J.; Ferreira, S.; Funston, P.J.; Hofmeyr, D.; Kilian, P.J. Management of reintroduced lions in small, fenced reserves in South Africa: An assessment and guidelines. Afr. J. Wildl. Res. 2013, 43, 138-154. [CrossRef]

53. Norton, B.B.; Tunseth, D.; Holder, K.; Briggs, M.; Hayek, L.-A.; Murray, S. Causes of morbidity in captive African lions (Panthera leo) in North America, 2001-2016. Zoo Biol. 2018, 37, 354-359. [CrossRef]

54. Oates, L.; Rees, P.A. The historical ecology of the large mammal populations of $\mathrm{N}$ gorongoro $\mathrm{C}$ rater, $\mathrm{T}$ anzania, east A frica. Mammal Rev. 2013, 43, 124-141. [CrossRef]

55. O'brien, S.J.; Troyer, J.L.; Brown, M.A.; Johnson, W.E.; Antunes, A.; Roelke, M.E.; Pecon-Slattery, J. Emerging viruses in the Felidae: Shifting paradigms. Viruses 2012, 4, 236-257. [CrossRef] [PubMed]

56. Olarte-Castillo, X.A.; Hofer, H.; Goller, K.V.; Martella, V.; Moehlman, P.D.; East, M.L. Divergent sapovirus strains and infection prevalence in wild carnivores in the Serengeti ecosystem: A long-term study. PLoS ONE 2016, 11, e0163548. [CrossRef] [PubMed]

57. Packer, C. The African lion: A long history of interdisciplinary research. Front. Ecol. Evol. 2019, 7, 259. [CrossRef]

58. Rafiqi, S.I.; Kumar, S.; Reena, K.K.; Garg, R.; Ram, H.; Karikalan, M.; Mahendran, K.; Pawde, A.M.; Sharma, A.K.; BANERJEE10, P. Molecu-lar characterization of Hepatozoon sp. and Babesia sp. isolated from endangered asiatic lion (Panthera leo persica). Indian J. Anim. Sci. 2018, 88, 662-666.

59. Watts, H.E.; Holekamp, K.E. Ecological determinants of survival and reproduction in the spotted hyena. J. Mammal. 2009, 90, 461-471. [CrossRef] 
60. Chaber, A.-L.; Cozzi, G.; Broekhuis, F.; Hartley, R.W.; McNutt, J. Serosurvey for selected viral pathogens among sympatric species of the African large predator guild in northern Botswana. J. Wildl. Dis. 2017, 53, 170-175. [CrossRef]

61. Risi, E.; Agoulon, A.; Allaire, F.; Le Dréan-Quénec'hdu, S.; Martin, V.; Mahl, P. Antibody response to vaccines for rhinotracheitis, caliciviral disease, panleukopenia, feline leukemia, and rabies in tigers (Panthera tigris) and lions (Panthera leo). J. Zoo Wildl. Med. 2012, 43, 248-255. [CrossRef]

62. Trinkel, M.; Cooper, D.; Packer, C.; Slotow, R. Inbreeding depression increases susceptibility to bovine tuberculosis in lions: An experimental test using an inbred-outbred contrast through translocation. J. Wildl. Dis. 2011, 47, 494-500. [CrossRef]

63. Adams, H.; Van Vuuren, M.; Kania, S.; Bosman, A.-M.; Keet, D.; New, J.; Kennedy, M. Sensitivity and specificity of a nested polymerase chain reaction for detection of lentivirus infection in lions (Panthera leo). J. Zoo Wildl. Med. 2010, 41, 608-615. [CrossRef]

64. Broughton, H.M.; Govender, D.; Shikwambana, P.; Chappell, P.; Jolles, A. Bridging gaps between zoo and wildlife medicine: Establishing reference intervals for free-ranging african lions (panthera leo). J. Zoo Wildl. Med. 2017, 48, 298-311. [CrossRef] [PubMed]

65. Filoni, C.; Helfer-Hungerbuehler, A.K.; Catão-Dias, J.L.; Marques, M.C.; Torres, L.N.; Reinacher, M.; Hofmann-Lehmann, R. Putative progressive and abortive feline leukemia virus infection outcomes in captive jaguarundis (Puma yagouaroundi). Virol. J. 2017, 14, 226. [CrossRef] [PubMed]

66. Fountain-Jones, N.M.; Packer, C.; Troyer, J.L.; VanderWaal, K.; Robinson, S.; Jacquot, M.; Craft, M.E. Linking social and spatial networks to viral community phylogenetics reveals subtype-specific transmission dynamics in African lions. J. Anim. Ecol. 2017, 86, 1469-1482. [CrossRef] [PubMed]

67. Hayward, J.J.; Rodrigo, A.G. Molecular epidemiology of feline immunodeficiency virus in the domestic cat (Felis catus). Vet. Immunol. Immunopathol. 2010, 134, 68-74. [CrossRef]

68. Kerr, T.J.; Matthee, S.; Govender, D.; Tromp, G.; Engelbrecht, S.; Matthee, C.A. Viruses as indicators of contemporary host dispersal and phylogeography: An example of feline immunodeficiency virus (FIVP le) in free-ranging African lion (Panthera leo). J. Evol. Biol. 2018, 31, 1529-1543. [CrossRef]

69. Roelke, M.E.; Brown, M.A.; Troyer, J.L.; Winterbach, H.; Winterbach, C.; Hemson, G.; Smith, D.; Johnson, R.C.; Pecon-Slattery, J.; Roca, A.L. Pathological manifestations of feline immunodeficiency virus (FIV) infection in wild African lions. Virology 2009, 390, 1-12. [CrossRef]

70. Troyer, J.L.; Roelke, M.E.; Jespersen, J.M.; Baggett, N.; Buckley-Beason, V.; MacNulty, D.; Craft, M.; Packer, C.; Pecon-Slattery, J.; O'Brien, S.J. FIV diversity: FIVPle subtype composition may influence disease outcome in African lions. Vet. Immunol. Immunopathol. 2011, 143, 338-346. [CrossRef]

71. Van Hooft, P.; Keet, D.F.; Brebner, D.K.; Bastos, A.D. Genetic insights into dispersal distance and disperser fitness of African lions (Panthera leo) from the latitudinal extremes of the Kruger National Park, South Africa. BMC Genet. 2018, 19, 21. [CrossRef]

72. Meoli, R.; Eleni, C.; Cavicchio, P.; Tonnicchia, M.C.; Biancani, B.; Galosi, L.; Rossi, G. B-cell chronic lymphocytic leukaemia in an African lion (Panthera leo). Veterinární Med. 2018, 63, 433-437. [CrossRef]

73. Harrison, T.M.; McKnight, C.A.; Sikarskie, J.G.; Kitchell, B.E.; Garner, M.M.; Raymond, J.T.; Fitzgerald, S.D.; Valli, V.E.; Agnew, D.; Kiupel, M. Malignant lymphoma in African lions (Panthera leo). Vet. Pathol. 2010, 47, 952-957. [CrossRef]

74. Mourier, T.; Mollerup, S.; Vinner, L.; Hansen, T.A.; Kjartansdóttir, K.R.; Frøslev, T.G.; Boutrup, T.S.; Nielsen, L.P.; Willerslev, E.; Hansen, A.J. Characterizing novel endogenous retroviruses from genetic variation inferred from short sequence reads. Sci. Rep. 2015, 5, 15644. [CrossRef]

75. Duarte, M.D.; Barros, S.C.; Henriques, M.; Fernandes, T.L.; Bernardino, R.; Monteiro, M.; Fevereiro, M. Fatal infection with feline panleukopenia virus in two captive wild carnivores (Panthera tigris and Panthera leo). J. Zoo Wildl. Med. 2009, 40, 354-359. [CrossRef]

76. Gillman, L.; Sánchez, A.M.; Arbiza, J. Picobirnavirus in captive animals from Uruguay: Identification of new hosts. Intervirology 2013, 56, 46-49. [CrossRef] [PubMed]

77. Ahasan, M.S.; Subramaniam, K.; Sayler, K.A.; Loeb, J.C.; Popov, V.L.; Lednicky, J.A.; Wisely, S.M.; Krauer, J.M.C.; Waltzek, T.B. Molecular characterization of a novel reassortment Mammalian orthoreovirus type 2 isolated from a Florida white-tailed deer fawn. Virus Res. 2019, 270, 197642. [CrossRef] [PubMed]

78. Orbell, G.M.B.; Young, S.; Munday, J.S. Cutaneous sarcoids in captive African lions associated with feline sarcoid-associated papillomavirus infection. Vet. Pathol. 2011, 48, 1176-1179. [CrossRef] 
79. Kraberger, S.; Serieys, L.; Fountain-Jones, N.; Packer, C.; Riley, S.; Varsani, A. Novel smacoviruses identified in the faeces of two wild felids: North American bobcat and African lion. Arch. Virol. 2019, 164, 2395-2399. [CrossRef] [PubMed]

80. Chhibber-Goel, J.; Joshi, S.; Sharma, A. Aminoacyl tRNA synthetases as potential drug targets of the Panthera pathogen Babesia. Parasites Vectors 2019, 12, 482. [CrossRef]

81. Githaka, N.; Konnai, S.; Kariuki, E.; Kanduma, E.; Murata, S.; Ohashi, K. Molecular detection and characterization of potentially new Babesia and Theileria species/variants in wild felids from Kenya. Acta Trop. 2012, 124, 71-78. [CrossRef] [PubMed]

82. Williams, B.M.; Berentsen, A.; Shock, B.C.; Teixiera, M.; Dunbar, M.R.; Becker, M.S.; Yabsley, M.J. Prevalence and diversity of Babesia, Hepatozoon, Ehrlichia, and Bartonella in wild and domestic carnivores from Zambia, Africa. Parasitol. Res. 2014, 113, 911-918. [CrossRef]

83. Di Cesare, A.; Laiacona, F.; Iorio, R.; Marangi, M.; Menegotto, A. Aelurostrongylus abstrusus in wild felids of South Africa. Parasitol. Res. 2016, 115, 3731-3735. [CrossRef]

84. Berentsen, A.R.; Becker, M.S.; Stockdale-Walden, H.; Matandiko, W.; McRobb, R.; Dunbar, M.R. Survey of gastrointestinal parasite infection in African lion (Panthera leo), African wild dog (Lycaon pictus) and spotted hyaena (Crocuta crocuta) in the Luangwa Valley, Zambia. Afr. Zool. 2012, 47, 363-368. [CrossRef]

85. Seltmann, A.; Webster, F.; Ferreira, S.C.M.; Czirják, G.Á.; Wachter, B. Age-specific gastrointestinal parasite shedding in free-ranging cheetahs (Acinonyx jubatus) on Namibian farmland. Parasitol. Res. 2019, 118, 851-859. [CrossRef]

86. Dubey, J.P. A review of Cystoisospora felis and C. rivolta-induced coccidiosis in cats. Vet. Parasitol. 2018, 263, 34-48. [CrossRef] [PubMed]

87. Alvarado-Esquivel, C.; Gayosso-Dominguez, E.A.; Villena, I.; Dubey, J.P. Seroprevalence of Toxoplasma gondii infection in captive mammals in three zoos in Mexico City, Mexico. J. Zoo Wildl. Med. 2013, 803-806. [CrossRef] [PubMed]

88. Ferreira, S.C.M.; Torelli, F.; Klein, S.; Fyumagwa, R.; Karesh, W.B.; Hofer, H.; Seeber, F.; East, M.L. Evidence of high exposure to Toxoplasma gondii in free-ranging and captive African carnivores. Int. J. Parasitol. Parasites Wildl. 2019, 8, 111-117. [CrossRef] [PubMed]

89. Eom, K.S.; Park, H.; Lee, D.; Choe, S.; Kang, Y.; Bia, M.M.; Lee, S.-H.; Keyyu, J.; Fyumagwa, R.; Jeon, H.-K. Molecular and morphologic identification of Spirometra ranarum found in the stool of African lion, Panthera leo in the Serengeti plain of Tanzania. Korean J. Parasitol. 2018, 56, 379. [CrossRef]

90. Eom, K.S.; Park, H.; Lee, D.; Choe, S.; Kang, Y.; Bia, M.M.; Ndosi, B.A.; Nath, T.C.; Eamudomkarn, C.; Keyyu, J. Identity of Spirometra theileri from a Leopard (Panthera pardus) and Spotted Hyena (Crocuta crocuta) in Tanzania. Korean J. Parasitol. 2019, 57, 639-645. [CrossRef] [PubMed]

91. Jeon, H.-K.; Kim, K.-H.; Sohn, W.-M.; Eom, K.S. Differential Diagnosis of Human Sparganosis Using Multiplex PCR. Korean J. Parasitol. 2018, 56, 295. [CrossRef]

92. Eberhard, M.L.; Thiele, E.A.; Yembo, G.E.; Yibi, M.S.; Cama, V.A.; Ruiz-Tiben, E. Thirty-Seven Human Cases of Sparganosis from Ethiopia and South Sudan Caused by Spirometra Spp. Am. J. Trop. Med. Hyg. 2015, 93, 350-355. [CrossRef]

93. Anderson, N.E.; Mubanga, J.; Fevre, E.M.; Picozzi, K.; Eisler, M.C.; Thomas, R.; Welburn, S.C. Characterisation of the wildlife reservoir community for human and animal trypanosomiasis in the Luangwa Valley, Zambia. PLoS Negl. Trop. Dis. 2011, 5. [CrossRef]

94. Sheng, Z.-H.; Chang, Q.-C.; Tian, S.-Q.; Lou, Y.; Zheng, X.; Zhao, Q.; Wang, C.-R. Characterization of Toxascaris leonina and Tococara canis from cougar (Panthera leo) and common wolf (Canis lupus) by nuclear ribosomal DNA sequences of internal transcribed spacers. Afr. J. Microbiol. Res. 2012, 6, 3545-3549.

95. Xue, L.-M.; Chai, J.-B.; Guo, Y.-N.; Zhang, L.-P.; Li, L. Further studies on Toxascaris leonina (Linstow, 1902) (Ascaridida: Ascarididae) from Felis lynx (Linnaeus) and Panthera leo (Linnaeus) (Carnivora: Felidae). Acta Parasitol. 2015, 60, 146-153. [CrossRef]

96. Marucci, G.; La Grange, L.J.; La Rosa, G.; Pozio, E. Trichinella nelsoni and Trichinella T8 mixed infection in a lion (Panthera leo) of the Kruger National Park (South Africa). Vet. Parasitol. 2009, 159, 225-228. [CrossRef] [PubMed]

97. Maruping-Mzileni, N.T.; Funston, P.J.; Ferreira, S.M. State-shifts of lion prey selection in the Kruger National Park. Wildl. Res. 2017, 44, 28-39. [CrossRef] 
98. Groom, R.J.; Funston, P.J.; Mandisodza, R. Surveys of lions Panthera leo in protected areas in Zimbabwe yield disturbing results: What is driving the population collapse? Oryx 2014, 48, 385-393. [CrossRef]

99. Roos, E.O.; Olea-Popelka, F.; Buss, P.; Hausler, G.A.; Warren, R.; Van Helden, P.D.; Parsons, S.D.; de Klerk-Lorist, L.-M.; Miller, M.A. Measuring antigen-specific responses in Mycobacterium bovis-infected warthogs (Phacochoerus africanus) using the intradermal tuberculin test. BMC Vet. Res. 2018, 14, 1-7. [CrossRef]

100. Viljoen, I.M.; Van Helden, P.D.; Millar, R.P. Mycobacterium bovis infection in the lion (Panthera leo): Current knowledge, conundrums and research challenges. Vet. Microbiol. 2015, 177, 252-260. [CrossRef]

101. McCain, S.; Allender, M.C.; Schumacher, J.; Ramsay, E. The effects of a probiotic on blood urea nitrogen and creatinine concentrations in large felids. J. Zoo Wildl. Med. 2011, 42, 426-429. [CrossRef]

102. Gross-Tsubery, R.; Chai, O.; Shilo, Y.; Miara, L.; Horowitz, I.H.; Shmueli, A.; Aizenberg, I.; Hoffman, C.; Reifen, R.A.M.; Shamir, M.H. Computed tomographic analysis of calvarial hyperostosis in captive lions. Vet. Radiol. Ultrasound 2010, 51, 34-38. [CrossRef]

103. Saqib, M.; Abbas, G.; Mughal, M.N. Successful management of ivermectin-induced blindness in an African lion (Panthera leo) by intravenous administration of a lipid emulsion. BMC Vet. Res. 2015, 11, 287. [CrossRef]

104. Loots, A.K.; Cardoso-Vermaak, E.; Venter, E.H.; Mitchell, E.; Kotzé, A.; Dalton, D.L. The role of toll-like receptor polymorphisms in susceptibility to canine distemper virus. Mamm. Biol. 2018, 88, 94-99. [CrossRef]

105. Deem, S.L.; Spelman, L.H.; Yates, R.A.; Montali, R.J. Canine distemper in terrestrial carnivores: A review. J. Zoo Wildl. Med. 2000, 31, 441-451. [PubMed]

106. Steinel, A.; Parrish, C.R.; Bloom, M.E.; Truyen, U. Parvovirus infections in wild carnivores. J. Wildl. Dis. 2001, 37, 594-607. [CrossRef] [PubMed]

107. Keet, D.F.; Michel, A.L.; Bengis, R.G.; Becker, P.; Van Dyk, D.S.; Van Vuuren, M.; Rutten, V.; Penzhorn, B.L. Intradermal tuberculin testing of wild African lions (Panthera leo) naturally exposed to infection with Mycobacterium bovis. Vet. Microbiol. 2010, 144, 384-391. [CrossRef]

108. Lane, E.P.; Brettschneider, H.; Caldwell, P.; Oosthuizen, A.; Dalton, D.L.; du Plessis, L.; Steyl, J.; Kotze, A. Feline panleukopaenia virus in captive non-domestic felids in South Africa. Onderstepoort J. Vet. Res. 2016, 83, 1-8. [CrossRef]

109. Moudgil, A.D.; Singla, L.D.; Singh, M.P. An issue of Public Health concern due to emerging drug resistance against Toxascaris leonina (Linstow, 1909) in Asiatic lions (Panthera leo persica). Int. J. Infect. Dis. 2016, 45, 105. [CrossRef]

110. Bentubo, H.D.L.; Fedullo, J.D.L.; Corrêa, S.H.R.; Teixeira, R.H.F.; Coutinho, S.D. Isolation of Microsporum gypseum from the haircoat of health wild felids kept in captivity in Brazil. Braz. J. Microbiol. 2006, 37, 148-152. [CrossRef]

111. Anonymous Personal Comms; 2019.

112. World Health Organisation Neglected Tropical Diseases; World Health Organisation: Geneva, Switzerland, 2020.

113. Odeniran, P.O.; Ademola, I.O. Zoonotic parasites of wildlife in Africa: A review. Afr. J. Wildl. Res. 2016, 46, 1-13. [CrossRef]

114. De Garine-Wichatitsky, M.; Caron, A.; Kock, R.; Tschopp, R.; Munyeme, M.; Hofmeyr, M.; Michel, A. A review of bovine tuberculosis at the wildlife-livestock-human interface in sub-Saharan Africa. Epidemiol. Infect. 2013, 141, 1342-1356. [CrossRef]

115. Probst, C.; Parry, C.D.; Rehm, J. Socio-economic differences in HIV/AIDS mortality in South Africa. Trop. Med. Int. Health 2016, 21, 846-855. [CrossRef]

116. Tadokera, R.; Bekker, L.-G.; Kreiswirth, B.N.; Mathema, B.; Middelkoop, K. TB transmission is associated with prolonged stay in a low socio-economic, high burdened TB and HIV community in Cape Town, South Africa. BMC Infect. Dis. 2020, 20, 120. [CrossRef] [PubMed]

117. Kiers, A.; Klarenbeek, A.; Mendelts, B.; Van Soolingen, D.; Koëter, G. Transmission of Mycobacterium pinnipedii to humans in a zoo with marine mammals. Int. J. Tuberc. Lung Dis. 2008, 12, 1469-1473. [PubMed]

118. IUCN SSC Cat Specialist Group 2020. Available online: https://www.facebook.com/IUCN-SSC-Cat-SpecialistGroup-1478766355730648/ (accessed on 29 August 2020).

119. Peiris, J.M.; De Jong, M.D.; Guan, Y. Avian influenza virus (H5N1): A threat to human health. Clin. Microbiol. Rev. 2007, 20, 243-267. [CrossRef] [PubMed]

120. Opriessnig, T.; Huang, Y. Update on possible animal sources for COVID-19 in humans. Xenotransplantation 2020, 27. [CrossRef] 
121. Goldstein, J.D. Bronx Zoo Tiger is Sick with Coronavirus. The New York Times. 2020. Available online: https://www.nytimes.com/2020/04/06/science/tiger-cats-coronavirus.html (accessed on 13 August 2020).

122. Steenhuisen, F.J.; Lorimer, J.; Street, P. Didiza's Attempt to Legalise the Consumption of Wild Animals Is Unfathomable. Available online: https://www.da.org.za/2020/05/didizas-attempt-to-legalise-theconsumption-of-wild-animals-is-unfathomable. (accessed on 25 August 2020).

123. Daszak, P.; Cunningham, A.A.; Hyatt, A.D. Anthropogenic environmental change and the emergence of infectious diseases in wildlife. Acta Trop. 2001, 78, 103-116. [CrossRef]

124. Association of Zoos and Aquiariums African Lion Breeding Program Receives Award from Association of Zoos \& Aquariums. News Releases. 2018. Available online: https://www.aza.org/aza-news-releases/ posts/african-lion-breeding-program-receives-award-from-association-of-zoos--aquariums (accessed on 18 August 2020).

125. Williams, V.L.; Michael, J. Born captive: A survey of the lion breeding, keeping and hunting industries in South Africa. PLoS ONE 2019, 14, e0217409. [CrossRef]

126. Fobar, R. More than 100 Neglected Lions Found in a South African Breeding Facility. National Geographic. 2019. Available online: https://www.nationalgeographic.co.uk/animals/2019/05/more-100-neglected-lionsdiscovered-south-africa-breeding-facility (accessed on 12 August 2020).

127. Katz, B. 108 Neglected Lions Found on South African Breeding Farm. Smithsonian Magazine. 2019. Available online: https://www.smithsonianmag.com/smart-news/108-neglected-lions-found-south-african-breedingfarm-180972146/ (accessed on 20 August 2020).

128. Humphrey, T. Are happy chickens safer chickens? Poultry welfare and disease susceptibility. Br. Poult. Sci. 2006, 47, 379-391. [CrossRef]

129. Saragusty, J.; Shavit-Meyrav, A.; Yamaguchi, N.; Nadler, R.; Bdolah-Abram, T.; Gibeon, L.; Hildebrandt, T.B.; Shamir, M.H. Comparative skull analysis suggests species-specific captivity-related malformation in lions (Panthera leo). PLoS ONE 2014, 9, e94527. [CrossRef]

130. Beck, M.A.; Levander, O.A. Host nutritional status and its effect on a viral pathogen. J. Infect. Dis. 2000, 182, S93-S96. [CrossRef]

131. Woo, P.C.; Lau, S.K.; Yuen, K. Infectious diseases emerging from Chinese wet-markets: Zoonotic origins of severe respiratory viral infections. Curr. Opin. Infect. Dis. 2006, 19, 401-407. [CrossRef]

132. Wildlife Conservation Society. Commercial Wildlife Farms in Vietnam: A Problem or Solution for Conservation? Wildlife Conservation Society: Hanoi, Vietnam, 2008.

133. Coals, P.; Burnham, D.; Loveridge, A.; Macdonald, D.W.; Sas-Rolfes, M.T.; Williams, V.L.; Vucetich, J.A. The Ethics of Human-Animal Relationships and Public Discourse: A Case Study of Lions Bred for Their Bones. Animals 2019, 9, 52. [CrossRef] [PubMed]

134. Rendón-Franco, E.; Romero-Callejas, E.; Villanueva-García, C.; Osorio-Sarabia, D.; Muñoz-García, C.I. Cross transmission of gastrointestinal nematodes between captive neotropical felids and feral cats. J. Zoo Wildl. Med. 2013, 44, 936-940. [CrossRef]

135. Saegerman, C.; Dal Pozzo, F.; Humblet, M.-F. Reducing hazards for humans from animals: Emerging and re-emerging zoonoses. Ital. J. Public Health 2012, 9. [CrossRef]

136. Halliday, J.; Daborn, C.; Auty, H.; Mtema, Z.; Lembo, T.; de Bronsvoort, B.M.C.; Handel, I.; Knobel, D.; Hampson, K.; Cleaveland, S. Bringing together emerging and endemic zoonoses surveillance: Shared challenges and a common solution. Philos. Trans. R. Soc. B Biol. Sci. 2012, 367, 2872-2880. [CrossRef] [PubMed]

137. Halliday, J.E.B.; Hampson, K.; Hanley, N.; Lembo, T.; Sharp, J.P.; Haydon, D.T.; Cleaveland, S. Driving improvements in emerging disease surveillance through locally relevant capacity strengthening. Science 2017, 357, 146-148. [CrossRef]

(C) 2020 by the authors. Licensee MDPI, Basel, Switzerland. This article is an open access article distributed under the terms and conditions of the Creative Commons Attribution (CC BY) license (http://creativecommons.org/licenses/by/4.0/). 